\title{
Hubungan Panjang Berat Teripang Holothuria atra di Pulau Panjang, Jepara
}

\author{
Primaswatantri Permata $^{1}$, Suryono ${ }^{1}$, Frijona F. Lokollo ${ }^{2}$, Widianingsih ${ }^{1}$, Hadi Endrawati ${ }^{1}$, \\ Muhammad Zainuri ${ }^{3}$, Retno Hartati ${ }^{1 *}$ \\ ${ }^{1}$ Departemen Ilmu Kelautan, Fakultas Perikanan dan Ilmu Kelautan, Universitas Diponegoro \\ Jl. Prof.H.Soedarto S.H, Tembalang,Semarang, Jawa Tengah 50275 Indonesia \\ ${ }^{2}$ Program Studi Ilmu Kelautan, Fakultas Perikanan dan Ilmu Kelautan, Universitas Pattimura. \\ Jl. Mr. Chr Soplanit, Poka-Ambon. Indonesia \\ ${ }^{3}$ Departemen Oseanografi, Fakultas Perikanan dan Ilmu Kelautan, Universitas Diponegoro \\ Jl. Prof.H.Soedarto S.H, Tembalang,Semarang, Jawa Tengah 50275 Indonesia \\ Email : retnohartati.undip@yahoo.com
}

\begin{abstract}
Abstrak
Holothuria atra merupakan salah satu teripang dan sering dijumpai berasosiasi dengan padang lamun dan substrat pasir. Walaupun bernilai ekonomi rendah, secara ekologi mempunyai manfaat sebagai bioturbator dan mempunyai potensi dalam bidang farmaseutical. Teripang ini ditenukan hidup di Pulau Panjang, dengan karakteristik perairan tertutup dan dangkal dengan akses yang mudah untuk wisatawan maupun perikanan tangkap yang dapat menjadi tekanan bagi populasi teripang tersebut. Penelitian ini bertujuan untuk untuk mengetahui hubungan panjang dan berat populasi teripang $H$. atra di Pulau Panjang, Jepara pada lokasi padang lamun dan pecahan karang dimana $H$. atra banyak ditemukan. Metode penelitian yang dipergunakan adalah metode deskriptif eksploratif dengan melakukan pengambilan sampel $H$. atra dengan teknik sampling complete enumeration pada luas lokasi penelitian yang telah ditentukan. Hasil penelitian menunjukkan kepadatan teripang di stasiun padang lamun (Stasiun A) lebih rendah dengan distribusi ukuran yang lebih kecil daripada di stasiun pecahan karang (Stasiun B). Pada semua stasiun dan waktu pengambilan sampel, pola pertumbuhan relatif yang ditunjukkan oleh hubungan panjang dan berat teripang $H$. atra bersifat allometrik negatif dengan keeratan hubungan yag sangat kecil. Hal ini disebabkan oleh kesulitan pengukuran pada teripang yang bertubuh lunak dengan elastisitas dinding tubuh (integument), isi pada sistem pencernaan makanannya dan kandungan cairan coelomic (rongga tubuh) yang dapat membuat bias analisa.
\end{abstract}

Kata kunci : Teripang, Kepadatan, Distribusi Ukuran, Padang Lamun, Pecahan Karang

\section{Abstract \\ Length and Weight Relationship of Holothuria atra in Pulau Panjang, Jepara}

Holothuria atra is one of species sea cucumbers often found in association with seagrass beds and sand substrates. Although it has low economic value, ecologically it has benefits as a bioturbator and has potential in the pharmaceutical. It is found in Panjang Island, which has characteristic of closed and shallow waters with easy access for tourists and capture fisheries which can put pressure on the sea cucumber population. This study aimed to determine the relationship between length and weight of $H$. atra population in the seagrass bed and rubble area in Panjang Island, Jepara. The research method used is descriptive exploratory and $H$. atra were sampled using a complete enumeration sampling technique at a predetermined area of the research location. The results showed that the density of sea cucumbers at the seagrass beds station (Station A) was lower with a smaller size distribution than at the rubble station (Station B). At all stations and sampling times, the relative growth pattern shown by the correlation between length and weight of $H$. atra is negative allometric with very small relationship value. This was due to the difficulty of measuring soft-bodied sea cucumbers with the elasticity of the body wall (integument), the contents of the digestive system and coelomic fluid in the body cavity which can bias the analysis.

Keywords : Sea Cucumber, Density, Size Distribution, Seagrass Beds, Rubble

*Corresponding author

DOI:10.14710/buloma.v10i2.31662 http://ejournal.undip.ac.id/index.php/buloma

Diterima/Received : 16-07-2020

Disetujui/Accepted : 25-03-2021 


\section{PENDAHULUAN}

Holothuria atra merupakan spesies teripang dengan nilai ekonomi yang rendah namun mempunyai potensi yang menjanjikan untuk dibudidayakan. Spesies ini tersebar luas di kawasan Indo-Pasifik (Boyer et al., 1995) dan umumnya diekspor sebagai teripang kering (Choo, 2008; Kinch et al., 2008). Kandungan senyawa bioaktif $H$. atra, seperti senyawa flavonoid, fenolik, terpenoid, saponin, alkaloid yang sangat potensial untuk industri farmasi (Dhinakaran dan Lipton, 2014). Walaupun di Indonesia $H$. atra dibutuhkan di pasar lokal (Natan et al., 2016), namun di negara lain, misalkan di Papua Nugini, Kepulauan Solomon, India dan Ekuador (Conand, 2006; Friedman et al., 2006) eksploitasinya semakin meningkat, sehingga dikhawatirkan permintaan untuk pasar ekspor dari Indonesia juga akan semakin tinggi. Dengan meningkatnya eksploitasi $H$. atra, maka usaha untuk mempertahankan stoknya yang berkelanjutan serta pemahaman dinamika populasinya menjadi sangat penting.

Pulau Panjang merupakan wilayah di Kabupaten Jepara, dengan luas sekitar 19 hektar dan berjarak 1,5 mil dari Pantai Kartini Jepara. Karakteristik pulau ini ialah pantai berpasir putih dengan perairan yang dangkal. Substratnya terdiri dari padang lamun, terumbu karang dan rubble dan mempunyai air yang jernih (E-KKP3K, 2015). Terdapat 3 species teripang di Perairan Pulau Panjang, yaitu Holothuria atra, H. scabra dan $H$. leucospilota (Satria et al., 2014) dan H. atra adalah species yang paling banyak ditemukan berada pada substrat berpasir di habitat padang lamun dan pecahan karang (Hartati et al., 2017). Pulau Panjang Jepara menjadi salah satu tujuan untuk pariwisata bahari, dimana para wisatawan menikmati snorkeling dan berenang di pantainya. Meningkatnya jumlah penduduk dan berkembangnya pemanfaatan kawasan pesisir seperti wisata bahari dapat memberikan dampak negatif di perairan tersebut (Satria et al., 2014), demikian juga terhadap populasi teripang, terutama H. atra.

Informasi tentang kondisi hubungan antara ekobiologi dan populasi teripang lebih banyak berasal dari teripang ekonomis penting (Darsono, 2007; Dissanayake dan Stefansson, 2012) seperti $H$. scabra, sehingga untuk teripang yang penting secara ekologi seperti $H$. atra juga perlu dilakukan. Hartati et al. (2019) telah melakukan kajian awal populasi $H$. atra di P. Panjang, namun belum mengkaji hubungan panjang dan beratnya. Penelitian hubungan panjang berat telah dilakukan terhadap teripang di perairan Tanjung tiram, Konawe Selatan, Sulawesi Tenggara (Kaenda et al., 2016), H. scabra di Teluk Un, Maluku Tenggara (Natan et al., 2015), Perairan Maluku Tengah (Manuputty, 2019), H. atra di beberapa perairan Taman Nasional Karimunjawa (Panuluh et al., 2019) dan H. scabra, H. atra dan Bohadchia marmorata (Luhulima et al., 2020) di Maluku.

Penelitian tentang hubungan panjang berat teripang species yang lain juga telah dilakukan oleh beberapa lokasi, seperti pada $H$. spinifera, $B$. marmorata, Stichopus naso di Pantai Timur Laut Sri Lanka (Veronika et al., 2018), H. arenicola, $H$. pardalis dan $H$. verrucosa (Ahmed et al., 2018), Ohshimella ehrenbergii (Quratulan et al., 2018) di Pantai Karachi-Pakistan, Isostichopus fuscus di Mexico (Reyes-Bonilla et al., 2018), $H$. scabra di Fiji (Lee et al., 2018) dan di Zanzibar, Tanzania (Yusuf dan Yahya, 2020), H. tubulosa, $H$. polii, H. mammata dan $H$. sanctori di Laut Aegean, Turki (Aydın, 2020).

Kajian mengenai hubungan panjang dan berat digunakan sebagai data yang penting dalam managemen perikanan, sehingga penelitian ini bertujuan untuk mengetahui hubungan panjang dan berat populasi teripang $H$. atra di Pulau Panjang, Jepara. Informasi mengenai hubungan panjang dan berat teripang berguna untuk memprediksi pertumbuhan teripang yang akan diperlukan dalam pengelolaan sumberdaya teripang tersebut

\section{MATERI DAN METODE}

Materi penelitian ini adalah Holothuria atra yang ditemukan di lokasi penelitian, yaitu di perairan dekat dermaga Pulau Panjang, Kabupaten Jepara, pada 2 Stasiun, yaitu Stasiun A (padang lamun) yang berada pada posisi $6^{\circ} 34^{\prime} 36.09^{\prime \prime} \mathrm{S}$ dan $110^{\circ} 37^{\prime} 51.91 " \mathrm{E}$, dan Stasiun B (pecahan karang) dengan koordinat 6 $6^{\circ} 34^{\prime} 33.67 " \mathrm{~S}$ dan $110^{\circ} 37^{\prime} 52.20^{\prime \prime E}$ (Gambar 1). Kedua stasiun ini dipilih karena memiliki komponen dan karakteristik habitat yang berbeda. Metode penelitian yang dipergunakan adalah metode deskriptif eksploratif. Pendataan teripang dilakukan pada tanggal 30 Juni, 14 Juli, 28 Juli, 11 Agustus, dan 25 Agustus 2019 dengan menggunakan teknik sampling complete enumeration (FAO, 1998) dengan cara snorkeling pada area yang telah ditentukan dan telah 
dilakukan marking dengan menggunakan GPS (Global Positioning System). Area Stasiun A adalah 3678 meter $^{2}$ dan Stasiun B seluas 1376 meter $^{2}$. Teripang yang ditemukan di area penelitian di ambil secara keseluruhan, difoto dan ditimbang beratnya, kemudian dikembalikan lagi pada lokasi pengambilan sample semula. Pengukuran panjang dengan menggunakan aplikasi measure picture berdasarkan foto yang didapat. Total individu teripang yang ditemukan dihitung kepadatannya individu per total area.

Menurut Effendi (2002), panjang dapat dianggap sebagai suatu fungsi dari bobot, dan persamaan hubungan panjang berat teripang diolah dengan analisa regresi menggunakan rumus yang digunakan Ahmad et al. (2018), yaitu $\mathrm{W}=\mathrm{a}$ $\mathrm{L}^{\mathrm{b}}$, dimana $\mathrm{W}$ adalah berat total individu (gram), $\mathrm{L}$ adalah panjang total $(\mathrm{cm})$, a adalah ordinat intercept dan $b$ adalah kemiringan kurva. Kriteria pertumbuhan teripang menurut Ahmad et al. (2018) adalah pertumbuhan isometri pada saat

Stasiun A tertinggi pada bulan Juni dan berkisar 0,24-0,32 indv.m ${ }^{-2}$ lebih sedikit dibandingan di Stasiun B (tertinggi bulan Juni), yaitu 0,041-0,06 indv. $\mathrm{m}^{-2}$. Terdapat variasi kepadatan tiap stasiun berdasarkan waktu $b=3$ atau allometri pada saat $b>3$ (negatif) atau $b<$ 3 (positif).

\section{HASIL DAN PEMBAHASAN}

Survey pendahuluan yang dilakukan di Perairan Pulau Panjang (Gambar 1) menunjukkan bahwa terdapat ekosistem lamun dan rubble (pecahan karang) yang berdekatan dengan terumbu karang, dengan padang lamun dan berbagai biota laut seperti Ikan Baronang dan teripang yang bisa menjadi potensi ekonomi daerah Jepara. Air lautnya yang jernih dan dangkal di sekitaran pantai membuat beberapa ekosistem seperti terumbu karang dan lamun dapat terlihat. Pulau Panjang memiliki substrat berpasir dengan partikel kecil, padang lamun, terumbu karang dan pecahan karang (rubble). Teripang ditemukan di sekitar padang lamun (Stasiun A) bersembunyi diantara kanopi dan di Stasiun B di pecahan karang (Stasiun B) teripang ditemukan tertutup pasir. Kepadatan $H$. atra di sampling. Kepadatan tertinggi pada Stasiun A (lamun) pada bulan Juni sedangkan di Stasiun B (pecahan karang) adalah pada bulan Juni 2019 (Gambar 2). Kepadatan yang berbeda berdasarkan waktu pengamatan disebabkan oleh adanya

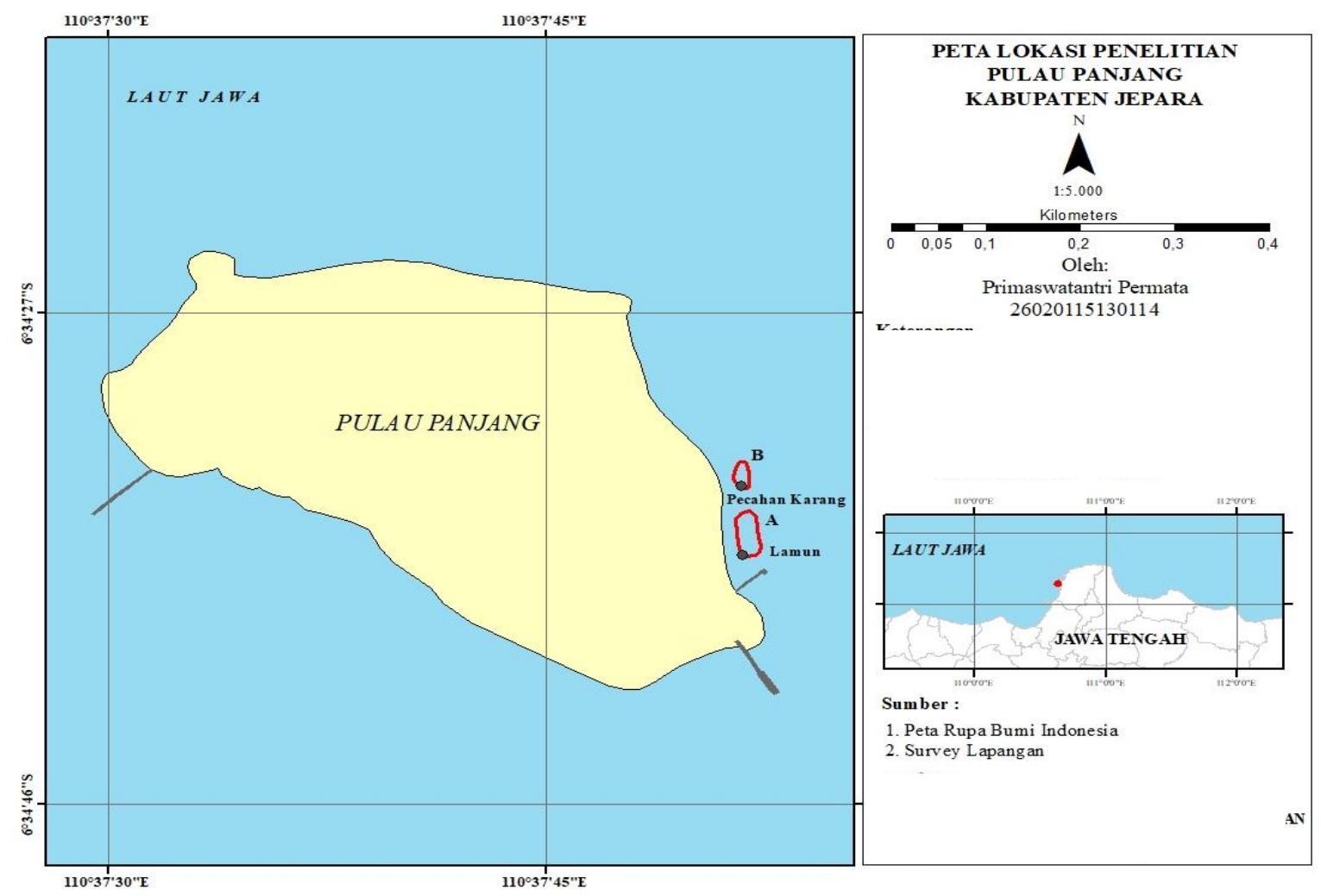

Gambar 1. Peta Lokasi Penelitian di Pulau Panjang, Jepara 
perubahan yang disebabkan oleh mortalitas, kelahiran, emigrasi dan imigrasi (Effendie, 2002; Dissanayake dan Stefansson, 2012). Pergerakan $H$. atra tidak bergitu jauh dan lokasi kedua stasiun yang berdekatan (berjarak 5 meter) di perairan dangkal dengan kedalaman berkisar 70-275 meter di Stasiun A dan 60-100 di Stasiun B. Substrat di kedua stasiun terdiri dari pasir halus dengan tumbuhan lamun atau pecahan karang.

Ukuran panjang yang terkecil pada Stasiun A dan B adalah 9 dan $8 \mathrm{~cm}$, sedangkan terbesar adalah 30 dan $27,3 \mathrm{~cm}$. Hasil distribusi ukuran panjang H. atra (Gambar 3) nampak bahwa pada di Stasiun A dan B menunjukkan sebaran yang bervariasi namun terdapat satu atau dua puncak yang berbeda. Ini berarti bahwa ada satu atau dua kelas ukuran panjang. Rata-rata frekuensi paling besar berapa pada kelas ukuran $17-19 \mathrm{~cm}$ di stasiun A sedakan pada Stasiun B bervariasi, 15$17 \mathrm{~cm}$ (sampling tanggal 28 Juli dan 11 Agustus) dan $19-21 \mathrm{~cm}$ pada sampling ke 5 pada tanggal 25 Agustus.

Distribusi panjang $H$. atra di Stasiun A pada semua waktu sampling mempunyai dua puncak, dan tidak adanya pergeseran atau pertumbuhan panjang dari waktu ke waktu penelitian. Namun pada Stasiun B yaitu pecahan karang/rubble, menunjukkan adanya pergeseran pada puncak grafik yang berarti terjadi pertumbuhan panjang dari waktu ke waktu penelitian sebanyak lima kali dan selama sekitar dua bulan dari Juni sampai Agustus.

Ukuran berat teripang $H$. atra yang terkecil pada Stasiun A dan B adalah 64 gram, sedangkan individu terberat berturut-turut adalah 312 dan 490 gram. Distribusi ukuran berat $H$. atra
(Gambar 4) nampak bahwa pada di Stasiun A hanya terdapat satu waktu dengan dua puncak kelas ukuran, sedangkan pada Stasiun B menunjukkan sebaran yang bervariasi dengan dua puncak kelas ukuran yang berbeda dengan Stasiun A. Hal ini berbeda dengan distribusi Panjang. Frekuensi individu paling besar di Stasiun A (lamun) terdapat pada kelas ukuran 188-219 gram di pada sampling tanggal 11 Agustus sedangkan pada Stasiun B (rubble/pecahan karang) pada ukura berat 126-157 gram pada tanggal 25 Agustus. Distribusi teripang $H$. atra di habitat pecahan karang bervariasi sampai ukuran yang besar 374-405 gram dan banyaknya ukuran teripang berukuran kecil dengan berat yang rendah di daerah lamun, dan hasil ini sama dengan hasil pengamatan Hartati et al. (2019) di lokasi yang hamper sama pada tahun 2017. Namun fenomena masuknya ukuran kelas (rekruitmen baru) yang kecil (kurang dari $7 \mathrm{~cm}$ atau 64 gram) yang diduga karena tidak ada kegiatan reproduksi baik seksual maupun aseksual pada bulan JuliAgustus 2019 ini.

Data ukuran panjang dan bobot/berat suatu individu dapat digunakan untuk mengetahui pola pertumbuhan organisme tersebut (Gayon, 2000). Pada penelitian ini hasil analisa hubungan panjang berat teripang $H$. atra di kedua stasiun (di padang lamun Stasiun A dan pecahan karang/rubble/ Stasiun B) dan semua waktu sampling menunjukkan nilai $\mathrm{b}$ kurang dari 3 yang termasuk pola pertumbuhan allometrik negatif baik (Gambar 5) yang berarti penambahan pertumbuhan panjang lebih cepat dari pada beratnya (Ahmad et al., 2018), dengan nilai b berkisar antara 0-0,3074 di Stasiun A yang dan

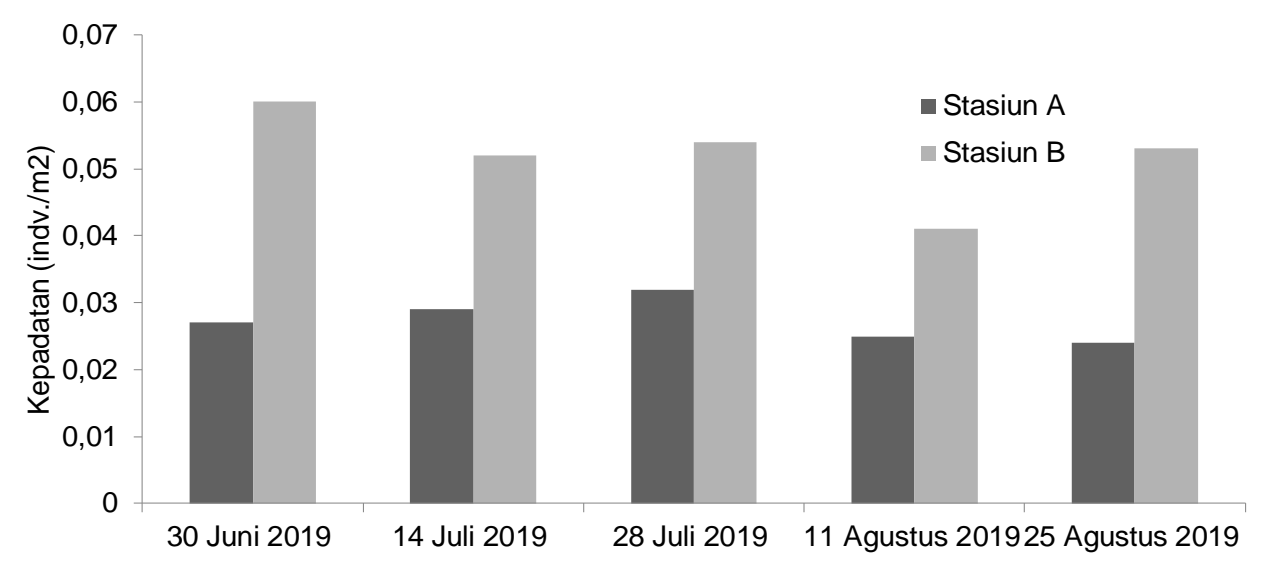

Gambar 2. Kepadatan H. atra (indv $/ \mathrm{m}^{2}$ ) di Stasiun A (lamun) dan B (pecahan karang) di Pulau Panjang, Jepara. 

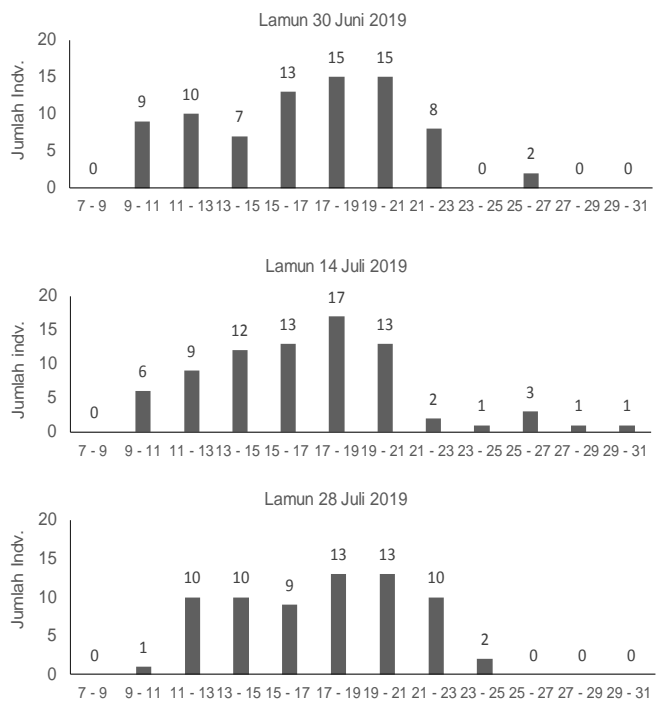

Lamun 11 Agustus 2019

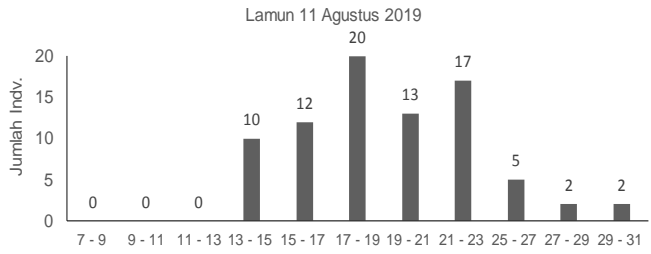

Lamun 25 Agustus 2019

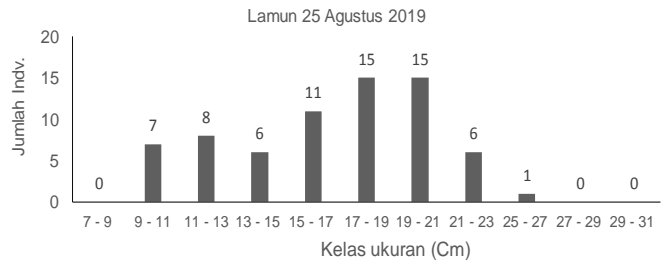

Stasiun A
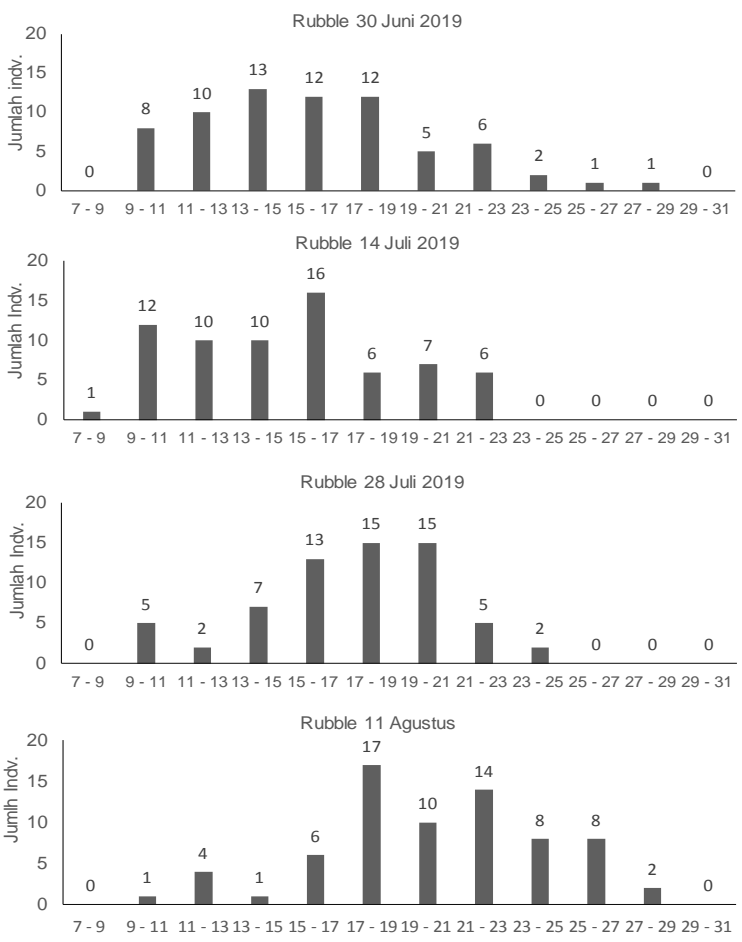

Rubble 25 Agustus 2019

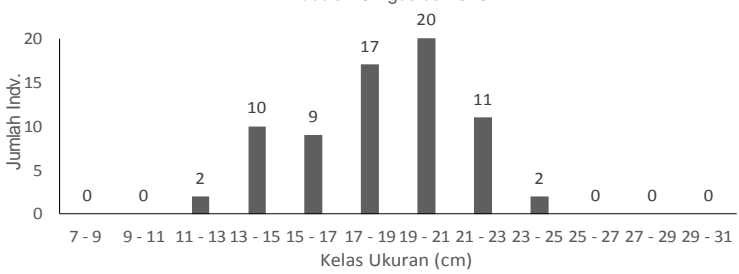

Stasiun B

Gambar 3. Distribusi kelas ukuran Panjang (cm) H. atra pada Stasiun A (lamun) dan B (rubble/pecahan karang) di Pulau Panjang, Jepara.

0,0447-03476 di Stasiun B. Pertumbuhan allometrik negatif yang sama juga terjadi pada $H$. atra yang hidup di perairan Pulau Karimunjawa (Panuluh et al., 2019) serta di pesisir Pulau Ambon, Saparua, Osi dan Marsegu, Provinsi Maluku (Luluhima et al., 2020).

Walaupun terdapat variasi nilai koefisien determinasi $\left(\mathrm{R}^{2}\right)$ pada nilai hubungan panjang dan berat $H$. atra antar stasiun dan waktu sampling tersebut, namun hubungan keeratan antara panjang dan berat $H$. atra sangat kecil yang termasuk kategori sangat lemah. Dalam hal ini pertambahan bobot tubuh teripang yang terjadi karena pertambahan panjang tubuh teripang sangat kecil, diduga disebabkan oleh hal yang lain, misalkan faktor lingkungan (eksternal) daninternal, misalkan umur dan jenis kelamin (Kaenda et al., 2016). Faktor eksternal berupa suhu, $\mathrm{pH}$, kandungan oksigen terlarut makanan, dan kompetitor atau predator juga mempengaruhi pertumbuhan (Hartati et al., 2017). Hal yang sama juga ditemukan pada penelitian Uneputty et al., (2014) pada $H$. atra yang dibudidaya dalam kurungan tancap di Pantai Negeri Ihamahu, Maluku Tengah, yang diduga disebabkan oleh tidak akuratnya proses penimbangan dan pengukuran panjang karena teripang mengandung air yang cukup banyak pada coelom (rongga tubuh)nya yang keluar menyebabkan tubuh teripang akan mengecil (mengerut). Menurut Poot-Salazar et al. (2014), kebanyakan metode untuk mengukur pertumbuhan menggunakan data frekuensi panjang, yang sangat bergantung pada teknik pengukuran (panjang/berat)nya dan hubungan biometriknya. Lebih jauh dikatakannya, bahwa ketepatan pengukuran berat dan panjang 
pada teripang merupakan tantangan tersendiri. Dan pada teripang yang tubuhnya lunak (Prescott et al., 2015), elastisitas dinding tubuh (integument), isi pada sistem pencernaan makanannya (perut, usus dll) dan kandungan cairan coelomic (rongga tubuh dapat membuat bias analisa data frekuensi ukuran (panjang dan berat) (Poot-Salazar et al., 2014). Terdapat tiga metode pengukuran yang dapat digunakan, yaitu (1) Bobot/Berat, misalkan berat dalam air (immersed weight), berat kering (dried weight) (Hanah et al., 2012) dan/atau berat tanpa isi perut (gutted weight) (Mercier et al., 2000); (2) panjang, misalkan panjang ketika kontraksi (contracted) atau ketika rileks (relaxed) (LaboyNieves \& Conde, 2006); dan (3) indeks campuran (compound indices) yang mengkombinasikan parameter biometik yang berbeda (Watanabe et al., 2011). Menurut Poot-Salazar et al., (2014),
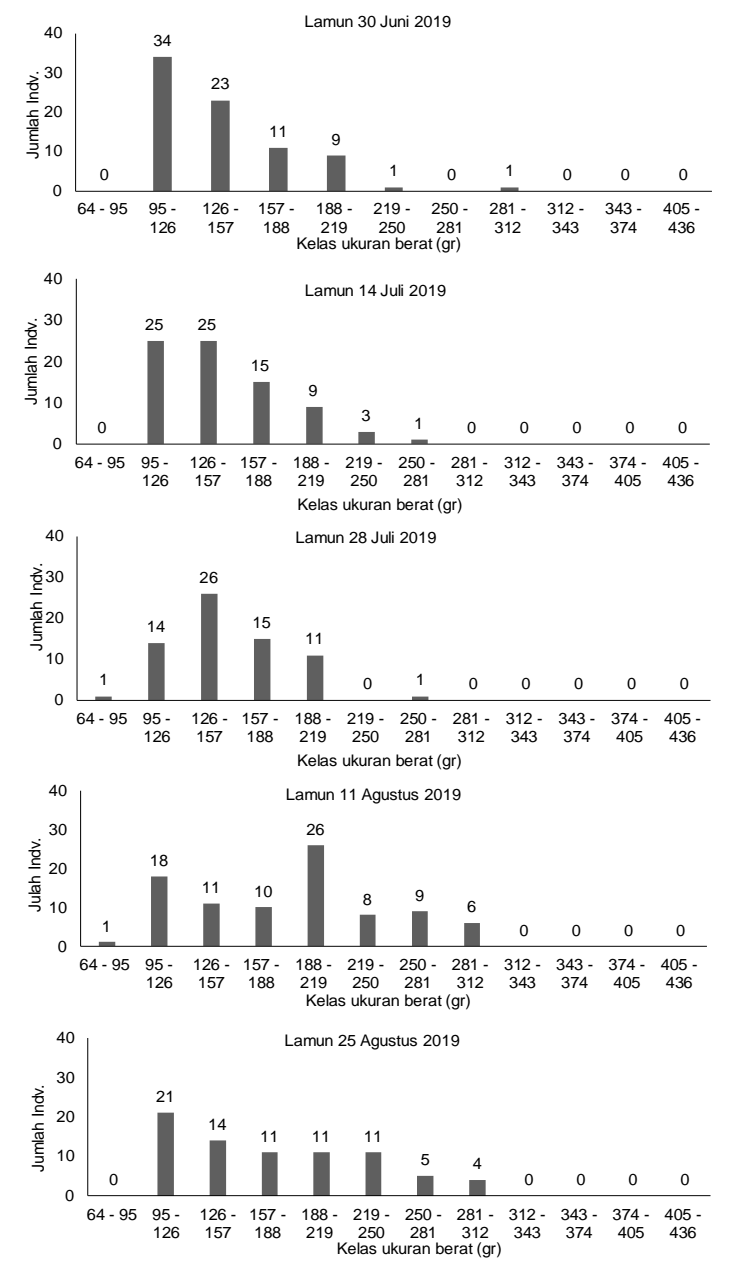

Stasiun A metode pengukuran dengan menggunakan indeks campuran dapat digunakan untuk menghitungbasal area dan volume, yang kemudian dapat diaplikasikan untuk mendapatkan hubungan biometrik yang lebih tepat Letak geografis wilayah dapat mempengaruhi ukuran dari individu. Menurut Satria et al. (2014) variasi pertumbuhan teripang dapat dipengaruhi oleh beberapa faktor, antara lain suhu perairan yang mempengaruhi kepadatan dan kelimpahan teripang. Kondisi perairan atau habitat dalam kondisi baik untuk mendukung kehidupan teripang dapat diindikasikan dengan kualitas perairan yang masih sesuai dan berada pada kisaran yang dapat ditolerir oleh teripang (Tabel 4). Kualitas perairan Pulau Panjang diukur bersamaan dengan pengambilan data panjang dan berat H.atra disajikan pada Tabel 4. Berdasarkan Hartati et al. (2017) kondisi dan kualitas perairan
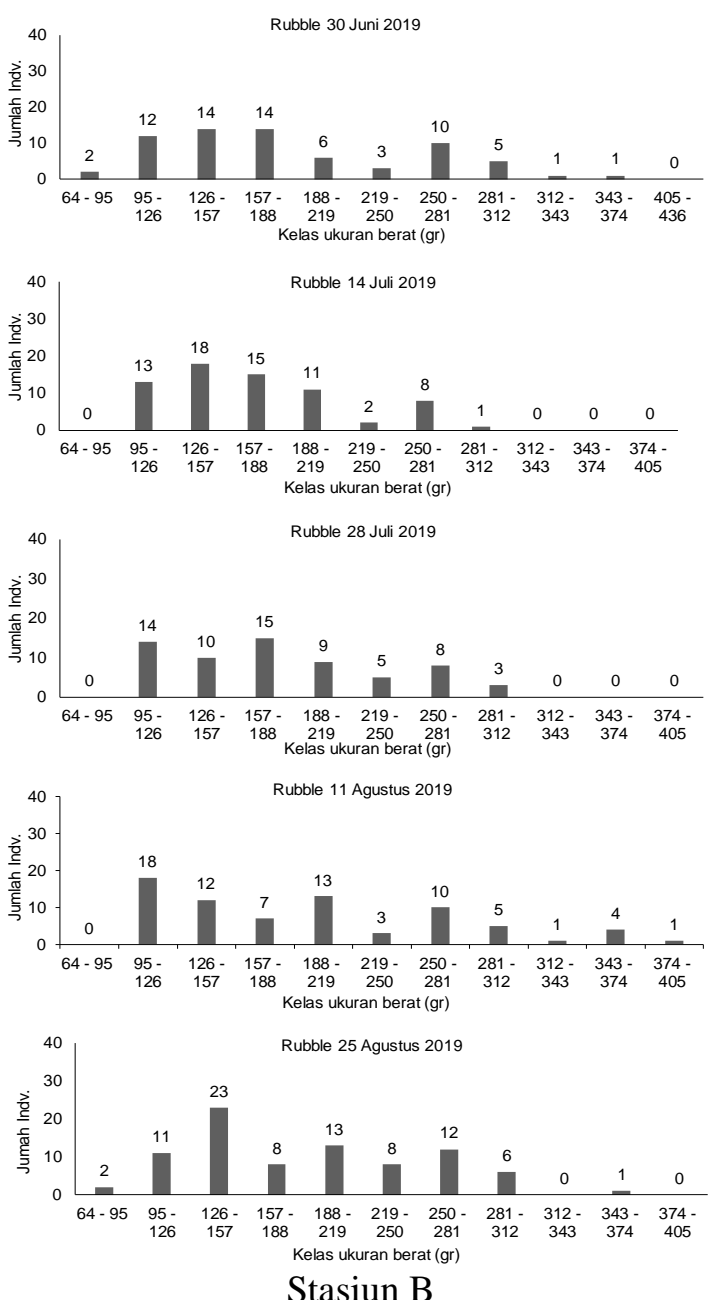

Stasiun B

Gambar 4. Distribusi kelas ukuran berat (gr) H. atra pada Stasiun A (lamun) dan B (pecahan karang) di Pulau Panjang, Jepara 

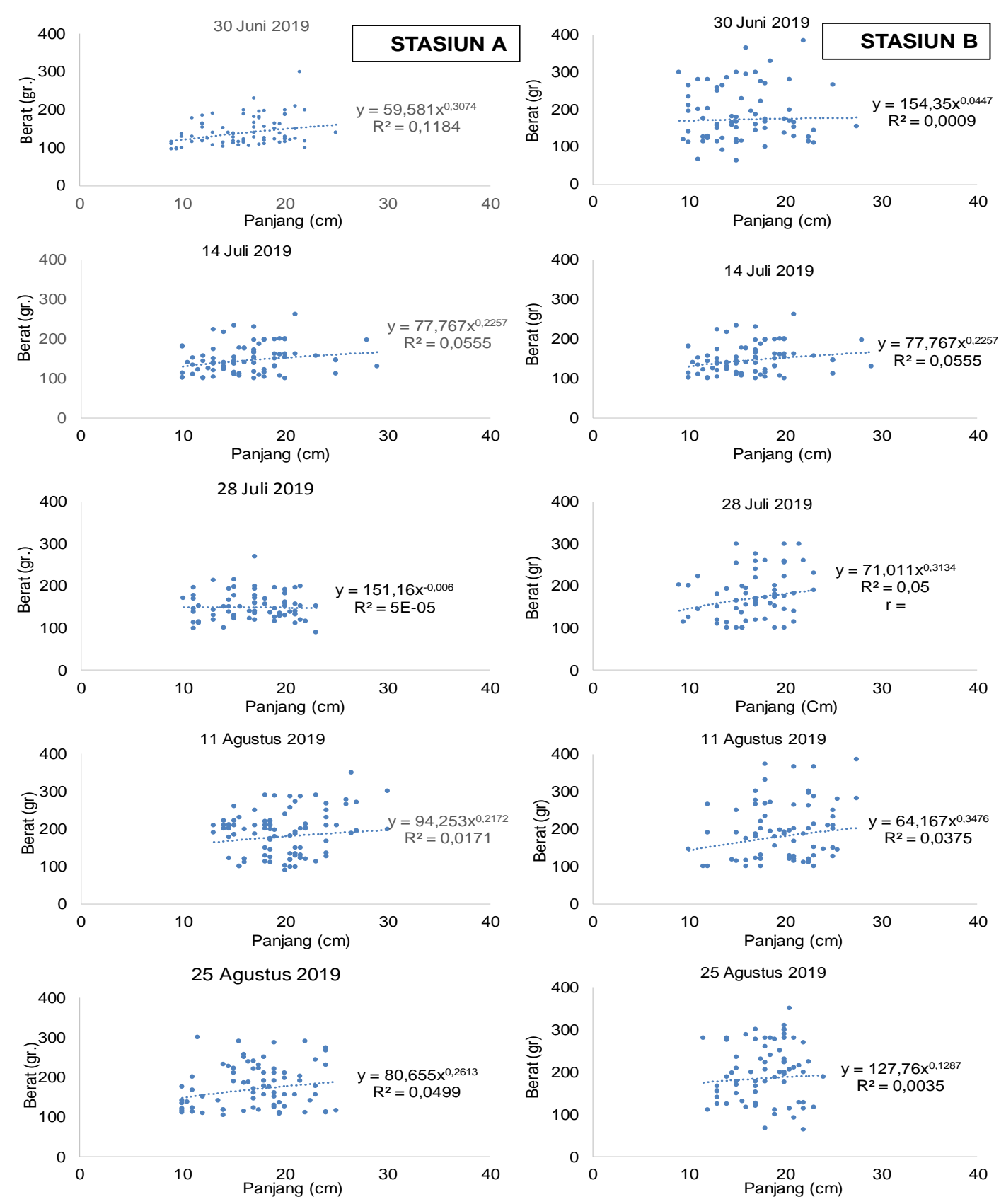

Gambar 5. Hubungan panjang (cm) dan berat (gr) H. atra pada Stasiun A (lamun) dan B (rubble/pecahan karang) di Pulau Panjang, Jepara

Tabel 4. Kualitas air pada Stasiun A dan Stasiun B, di Perairan Pulau Panjang, Jepara

\begin{tabular}{lcccc}
\hline Parameter & Satuan & Stasiun A & Stasiun B & $\begin{array}{c}\text { Kisaran optimal untuk H. atra } \\
\text { (Pustaka) }\end{array}$ \\
\hline Suhu & ${ }^{\circ} \mathrm{C}$ & $27-29,9$ & $26,9-29,9$ & $28-35$ (Hartati et al., 2017) \\
pH & - & $7,0-7,57$ & $7,86-7,91$ & $7-8$ (Hartati et al., 2017) \\
Salinitas & $\%_{\text {oo }}$ & $31,1-32,0$ & $32,0-32,4$ & $23-33$ (Hartati et al., 2017) \\
Kecepatan Arus & $\mathrm{cm.dt}-1$ & $5,80-7,50$ & $4,50-4,52$ & - \\
Kecerahan & $\mathrm{cm}$ & 275 & 110 & - \\
Kedalaman & $\mathrm{cm}$ & 275 & 110 & - \\
\hline
\end{tabular}


Pulau Panjang, Jepara dalam kondisi yang optimal dan sudah sesuai dengan kisaran optimal untuk kehidupan $H$. atra.

\section{KESIMPULAN}

Distribusi ukuran Panjang dan berat menunjukkan satu atau dua puncak kelas ukuran. Hubungan panjang berat teripang $H$. atra di area padang lamun (Stasiun A) dan pecahan karang/rubble (Stasiun B) pada semua waktu sampling menunjukkan pola pertumbuhan allometrik negatif, namun hubungan keduanya sangat lemah. Maka diduga ada faktor lain yang berpengaruh, yaitu teknik pengukuran dan faktor internal (umur dan jenis kelamin).

\section{DAFTAR PUSTAKA}

Ahmed, Q., Alicia Poot-Salazar, A., Qadeer Mohammad Ali, Q.M. \& Levent Bat, L. 2018. Seasonal Variation in the Length-Weight Relationships and Condition Factor of Four Commercially Important Sea Cucumbers Species from Karachi Coast-Northern Arabian Sea. NESciences 3(3):265-281. doi: 10.28978/nesciences.468667

Aydin, M. 2020. Length-weight relationships and condition factor of four different sea cucumber species in the Aegean Sea. $J$. Anatolian Env. and Anim. Sciences 5(1):8085

Boyer, C., Cailasson, S., \& Mairesse, K. 1995. Asexual reproduction in Holothuria atra on a reef of Reunion Island in the Indian Ocean. SPC Beche-de-mer Information Bulletin., 7:7-9.

Choo, P.S. 2008. Population status, fisheries and trade of sea cucumbers in Asia. In: Sea cucumbers. A global review of fisheries and trade. In: Toral-Granda, V., Lovatelli, A., Vasconcellos, M (eds). FAO Fisheries and Aquaculture Technical Paper. 16 (pp. 81118). Rome.

Conand, C. 2006. Harvest and trade: Utilization of sea cucumbers; sea cucumbers fisheries; current international trade; illegal, unreported and unregulated trade; bycatch; socioeconomic characteristics of the trade in sea cucumbers. p. 51-73. In: Bruckner A.W. (ed). Proceedings of the CITES workshop on the conservation of sea cucumbers in the families Holothuriidae and Stichopodidae. NOAA Technical Memorandum.. 244p.

Darsono, P. 2007. Teripang (Holothuridae):
Kekayaan Alam Dalam Keanekaragaman Biota Laut. Oseana XXXII (2):1-10.

Dhinakaran, D.I. \& Lipton, A.P. 2014. Pharmacological potentials of sea cucumber Holothuria atra extracts from the Indian Ocean. Asian J. Biomed. Pharm. Sci., 4:3643.

Dissanayake, D.C.T. \& Stefansson, G. 2012. Habitat preference of sea cucumbers: Holothuria atra and Holothuria edulis in the coastal waters of Sri Lanka. Journal of the Marine Biological Association of the United Kingdom. 92:581-593. doi: 10.1017/S0025 315411000051

Effendie MI. 2002. Biologi Perikanan. Yayasan Pustaka Nusantara. Yogyakarta. $163 \mathrm{hlm}$

E-KKP3K. 2015. Profil Kawasan Konservasi Provinsi Jawa Tengah. Kementerian Kelautan dan Perikanan, 45p

FAO, 1998. Guideline for the Routine Collection of Capture Fishery Data. DANIDA. Thailand $113 p$

Friedman, K., Eriksson, H., Tardy, E., \& Pakoa,K. 2011. Management of sea cucumber stocks: patterns of vulnerability and recovery of sea cucumber stocks impacted by fishing. Fish and Fisheries. 12:75-93. doi: 10.1111/j.14 67-2979.2010.00384.x

Gayon, J. 2000. History of the concept of allometry. America zoologist. 40(5):748-758.

Hannah, L., Duprey, N., Blackburn, J., Hand, C. M., \& Pearce, C.M. 2012. Growth rate of the California sea cucumber Parastichopus californicus: measurement accuracy and relationships between size and weight metrics. North American Journal of Fisheries Management32:167-176.

Hartati, R., Trianto, A., Widianingsih. 2017. Habitat Characteristic of Two Selected Locations for Sea Cucumber Ranching Purposes. IOP Conf. Series: Earth and Environmental Science 55:012041. doi: 10.1088/1755-1315/55/1/012041.

Hartati, R., Zainuri, M., Widianingsih, W., Ambariyanto, A., Mustagpirin, M., Ayodya F.P., Soegianto, A. 2019. Initial assessment of Holothuria atra in Panjang Island, Jepara, Indonesia. Eco. Env. \& Cons. 25 (July Suppl. Issue) : S1-S6.

Kaenda, H., Ishak, E. \& Afu, L.O.A. 2016. Hubungan panjang berat Teripang di perairan Tanjung Tiram, Konawe Selatan. Jurnal Manajemen Sumber Daya Perairan, 2(2): 171-177. 
Kinch, J., Purcell, S., Uthicke, S., \& Friedman, K. 2008. Population status, fisheries and trade of sea cucumbers in the Western Central Pacific. In: Sea cucumbers. A global review of fisheries and trade. In: Toral-Granda, V., Lovatelli, A., Vasconcellos, M. (Eds.). FAO Fisheries and Aquaculture Technical Paper, Rome. 516: 7-55.

Laboy-Nieves, E.N. \& Conde, J.E. 2006. A new approach for measuring Holothuria mexicana and Isostichopus badionotus for stock assessments. SPC Beche-de-mer Inf. Bull. 24: 39-44

Lee, S. Ford, A., Mangubhai, S., Wild, C., Ferse, S. 2018. Length-weight Relationship, Movement Rates, and In Situ Spawning Observations of Holothuria scabra (sandfish) in Fiji. SPC Beche-de-mer Information Bulletin 38:11-14.

Luhulima, Y., Zamani, N.P. \& Bengen, D.G. 2020. Kepadatan dan pola pertumbuhan teripang Holothuria scabra, Holothuria atra dan Bohadchia marmorata serta asosiasinya dengan lamun di pesisir Pulau Ambon, Saparua, Osi dan Marsegu, Provinsi Maluku. Jurnal Ilmu dan Teknologi Kelautan Tropis, 12(2):543-556. doi: 10.29244/jitkt.v12i2.23 454

Natan, Y., Uneputty, P.A., Lewerissa, \& Pattikawa, J.A. 2015. Species and size composition of sea cucumber in coastal waters of UN bay, Southeast Maluku, Indonesia. International Journal of Fisheries and Aquatic Studies, 3(1):251-256.

Natan, Y., Tetelepta, J.M., \& Uneputty, P.A. 2016. Sustainability of sea cucumber fishery at Central Maluku and Southeast Maluku Regency, Indonesia. AACL Bioflux, 9(1):3441.

Manuputty, G.D. 2019. Hubungan Panjang Bobot dan Faktor Kondisi Teripang Pasir (Holothuria scabra) di Perairan Suli, Maluku Tengah, Maluku. Agrikan, 12(1):174-181. doi: 10.29239/j.agrikan.12.1.174-181

Mercier, A., Battaglene, S.C. \& Hamel, J.F. 2000. Periodic movement, recruitment and sizerelated distribution of the sea cucumber Holothuria scabra in Solomon Islands. Hydrobiologia, 440:81-100.

Panuluh, C.M., Sulardiono, B. \& Latifah, N. 2020. Hubungan panjang berat dan faktor kondisi teripang hitam (Holothuria atra) di kawasan Taman Nasional Laut Karimunjawa. Management of Aquatic Resources Journal 8(4):327-336. doi : 10.14710/marj.v8i4.265 52

Poot-Salazar, A., Herna'ndez-Flores, A., \& Ardisson, P. 2014. Use of the SLW index to calculate growth function in the sea cucumber Isostichopus badionotus. Sci. Rep. 4: 5151. doi: 10.1038/srep05151.

Prescott, J., Zhou, S., \& Andhika P. Prasetyo, A.P. 2015, Soft bodies make estimation hard: correlations among body dimensions and weights of multiple species of sea cucumbers. Marine and Freshwater Research, 66:857-865. doi: 10.1071/MF1 4146

Quratulan,A., Qadeer, M.A. \& Sabri, B. 2018. Weight-length relationship of Sclerodactylidae sea cucumber, Ohshimella ehrenbergii (Selenka, 1868) (Echinodermata: Holothuroidea), from Karachi coast, Pakistan. SPC Beche-de-mer Information Bulletin, 38:79-80.

Satria, G.G.A., Sulardiono, B., \& Purwanti, F. 2014. Kelimpahan jenis teripang di perairan terbuka dan perairan tertutup Pulau Panjang Jepara, Jawa Tengah. Diponegoro Journal of Maquares Management of Aquatic Resources 3(1):108-115. doi: 10.14710/marj. v3i1.4427

Setyastuti, A. 2014. Echinodermata, Holothuria $a t r a$, in an intertidal seagrass bed off The Bama Beach, Baluran National Park, East Java, Indonesia. Jurnal Ilmu dan Teknologi Kelautan Tropis, 6(1):31-39. doi: 10.29244/ jitkt.v6i1.8625

Uneputty, P.A., Selanno, D.A.J., \& Tuhumury, S.F. 2014. Distribusi ukuran teripang pada Perairan Pantai Negeri Ihamahu. Jurnal Triton, 10(2):111-115

Veronika, K., Edrisinghe, U., Sivashanthini, K., Athauda, A.R.S.B. 2018. Length-Weight Relationships of Four Different Sea Cucumber Species in North-East Coastal Region of Sri Lanka. Tropical Agricultural Research, 29(2):212- 217.

Watanabe, S., Zarate, J.M., Sumbing, J.G., Hazel, M.J., Nievales, M.F. 2011. Size measurement and nutritional condition evaluation methods in sandfish (Holothuria scabra Jaeger). Aquaculture Research, 43: 940-948. 
Yussuf, Y.S., \& Yahya, S.A. 2020. Sizedistribution and length-weight relationship of a deep-water population of Holothuria scabra (Jaeger, 1833) in Zanzibar, Tanzania.
Western Indian Ocean Journal of Marine Science 19(1):113-121. doi: 10.4314/wio jms.v19i1.9 